\title{
Seasonal variation in seminal and testicular characteristics of Brazilian Somali rams in the hot semi-arid climate of tropical northeast Brazil
}

\author{
A. A. Simplício, G. S. Riera, E. A. Nelson* and K. P. Pant \\ Centro Nacional de Pesquisa de Caprinos-EMBRAPA, Caixa Postal 10, CEP 62.100 Sobral, Ce., \\ Brazil
}

\begin{abstract}
Summary. The seasons in the 1 year study were classified as rainy, transitional rainydry, dry, and transitional dry-rainy. Semen $\mathrm{pH}$ and the consistency of the testes did not vary between seasons or among rams. All other characteristics of semen and testis varied between rams. Significant seasonal differences were observed for ejaculate volume, mass, $\%$ motility, forward motility score and concentration of spermatozoa, and linear testis measurements. The total number of spermatozoa per ejaculate did not vary seasonally. The magnitude of the seasonal effects was not sufficient to prevent the rams being used for breeding throughout the year.
\end{abstract}

\section{Introduction}

Hairy breeds constitute a sizeable proportion of sheep population of Brazil and are being studied for their potential in the hot tropical climate (Figueiredo, Simplício \& Pant, 1982). The Brazilian Somali breed (Mason, 1980; Shelton \& Figueiredo, 1981) is a much modified and locally adapted version of the original import. Virtually no information is available on the reproductive behaviour of sheep in this region and an attempt has therefore been made to study seasonal variation in the characteristics of the semen and in the shape and size of the testes.

\section{Materials and Methods}

This experiment was carried out for 1 year with 5 rams of the Brazilian Somali breed which were 16-24 months of age at the beginning. All the rams were clinically examined once every 15 days for any symptoms of disease in general and of the genital organs in particular. The rams were already donating semen when the experiment started and for this study one ejaculate was collected once a week, between 08:00 and 09:00 h, using a short artificial vagina (Mies Filho, 1975). In all, there were 52 collections from each of 4 rams and 49 from the fifth.

Immediately after collection, the tube containing semen was placed in a water bath and brought to the laboratory. No precautions were necessary to avoid cold shock. The ejaculate volume was read in $0.1 \mathrm{ml}$ units. Semen colour and consistency was graded from 1 to 5 (turbid to thick creamy). Other seminal characteristics were measured according to standard methods. The proportion of unstained spermatozoa was estimated by differential staining using separate solutions of nigrosin and eosin.

* Present address: Animal Science Department, California State Polytechnic University at Pomona, 3801 West Temple Avenue, Pomona, Ca 91768, U.S.A. 
Vernier callipers were used to measure the scrotal skin thickness (Hahn, Foote \& Seidel, 1969) and the length and the anterior-posterior breadth of the testis. The testis shape index was calculated by multiplying the two linear measurements. Testicular circumference was measured with a tape and scrotal volume was determined by water displacement. The testes were graded on a 1-5 scale according to flaccidity or firmness. The procedure of least-squares analysis for general linear models (Barr, Goodnight, Sall \& Helwig, 1976) was used in the interpretation of the data.

\section{Results}

The seasonal variation in environmental temperature, rainfall and humidity is presented in Table 1. There was little variation in the temperature throughout the year but rainfall was concentrated in the months of January-April. The seasons were therefore classified as rainy (February-April), transitional rainy-dry (May-July), dry (August-October), and transitional dry-rainy (NovemberJanuary), and the results are given in Table 1.

Table 1. Least-squares means (s.e.) of seminal and testicular characteristics of Brazilian Somali rams and meteorological data in different seasons in tropical northeast Brazil

\begin{tabular}{|c|c|c|c|c|}
\hline \multirow[b]{2}{*}{ Characteristics } & \multicolumn{4}{|c|}{ Seasons } \\
\hline & Rainy & $\begin{array}{l}\text { Transitional } \\
\text { rainy-dry }\end{array}$ & Dry & $\begin{array}{c}\text { Transitional } \\
\text { dry-rainy }\end{array}$ \\
\hline Ejaculate vol. (ml) & $0.669(0.041)^{\mathrm{a}}$ & $0.776(0.025)^{b}$ & $0.685(0.028)^{a}$ & $0.632(0.024)^{a}$ \\
\hline Colour-consistency of semen (score 1-5) & $3.166(0.135)^{\mathrm{a}}$ & $3.600(0.084)^{b}$ & $3.667(0.093)^{\mathrm{b}}$ & $3.671(0.079)^{b}$ \\
\hline Mass motility (score $1-5$ ) & $3.875(0.087)^{b}$ & $3.993(0.054)^{b}$ & $3.880(0.059)^{\mathrm{b}}$ & $3.561(0.051)^{\mathrm{a}}$ \\
\hline$\%$ individual sperm motility & $67.65(1.24)^{\mathrm{ab}}$ & $68.42(0.77)^{\mathrm{b}}$ & $65.97(0.85)^{\mathrm{a}}$ & $65.01(0.72)^{\mathrm{a}}$ \\
\hline Forward sperm motility score $(1-5)$ & $3.968(0.075)^{b}$ & $3.934(0.047)^{\mathrm{b}}$ & $3.879(0.052)^{\mathrm{b}}$ & $3.684(0.044)^{a}$ \\
\hline Sperm conc. $\left(\times 10^{4} / \mathrm{mm}^{3}\right)$ & $242.55(13.82)^{a}$ & $248.77(8.55)^{\mathrm{a}}$ & $278 \cdot 18(9 \cdot 49)^{\mathrm{b}}$ & $278.80(8.04)^{\mathrm{b}}$ \\
\hline Total sperm no. ejaculate $\left(\times 10^{4}\right)$ & $167 \cdot 24(15 \cdot 14)^{a}$ & $202 \cdot 61(9 \cdot 37)^{\mathrm{a}}$ & $194.55(10 \cdot 39)^{a}$ & $177 \cdot 31(8 \cdot 80)^{\mathrm{a}}$ \\
\hline$\%$ stained sperm. & $19 \cdot 8(1.43)^{\mathrm{a}}$ & $20 \cdot 3(0 \cdot 89)^{a}$ & $23.50(0.98)^{\mathrm{b}}$ & $21.4(0.83)^{\mathrm{ab}}$ \\
\hline Semen $\mathrm{pH}$ & $7 \cdot 11(0.21)^{\mathrm{a}}$ & $7.01(0.08)^{\mathrm{a}}$ & $6.79(0.09)^{\mathrm{a}}$ & $6.87(0.10)^{a}$ \\
\hline Testis volume $(\mathrm{ml})$ & $434.7(13.9)^{\mathrm{ab}}$ & $443 \cdot 2(8 \cdot 2)^{\mathrm{b}}$ & $427 \cdot 1(9 \cdot 0)^{\mathrm{ab}}$ & $408.9(8 \cdot 1)^{\mathrm{a}}$ \\
\hline Testis consistency (score 1-5) & $2.99(0.14)^{\mathrm{a}}$ & $3.00(0.08)^{\mathrm{a}}$ & $3.15(0.09)^{\mathrm{a}}$ & $3.00(0.08)^{a}$ \\
\hline Average length of testis $(\mathrm{cm})(\mathrm{A})$ & $8.22(0.05)^{b c}$ & $8.09(0.03)^{\mathrm{a}}$ & $8.30(0.03)^{c}$ & $8.19(0.03)^{\mathrm{b}}$ \\
\hline \multicolumn{5}{|l|}{ Average diam. (breadth) } \\
\hline of testis $(\mathrm{cm})(\mathrm{B})$ & $5.86(0.06)^{c}$ & $5.56(0.04)^{a}$ & $5.78(0.04)^{\mathrm{bc}}$ & $5.69(0.03)^{\mathrm{b}}$ \\
\hline Testis shape $(A \times B)$ & $48.29(0.71)^{c}$ & $45.09(0.42)^{a}$ & $48.21(0.46)^{c}$ & $46.74(0.41)^{b}$ \\
\hline Circumference of testes $(\mathrm{cm})$ & $27.64(0.21)^{\mathrm{bc}}$ & $27.99(0.12)^{c}$ & $27 \cdot 27(0 \cdot 14)^{\mathrm{ab}}$ & $27.08(0 \cdot 12)^{a}$ \\
\hline Months & Feb.-Mar.-Apr. & May.-Jun.-Jul. & Aug.-Sep.-Oct. & Nov.-Dec.-Jan. \\
\hline Mean maximum temp. $\left({ }^{\circ} \mathrm{C}\right)$ & 32.03 & 34.50 & 35.77 & $35 \cdot 13$ \\
\hline Mean minimum temp. $\left({ }^{\circ} \mathrm{C}\right)$ & $23 \cdot 20$ & $22 \cdot 50$ & $23 \cdot 40$ & 23.97 \\
\hline Mean daytime temp. $\left({ }^{\circ} \mathrm{C}\right)$ & $26 \cdot 87$ & 27.83 & $28 \cdot 33$ & $28 \cdot 40$ \\
\hline Mean relative humidity $(\%)$ & $77 \cdot 00$ & $61 \cdot 00$ & 55.00 & 58.67 \\
\hline Total precipitation $(\mathrm{mm})$ & $476 \cdot 70$ & $33 \cdot 30$ & 0.40 & $84 \cdot 40$ \\
\hline
\end{tabular}

Means within rows with the same superscript letter are not significantly different $(P>0.05)$.

The $\mathrm{pH}$ of semen and the consistency score of the testes did not vary between rams or between seasons. All other measurements varied between rams. Differences were observed between seasons for ejaculate volume, percentage of motile spermatozoa and forward motility score, sperm concentration and the linear measurements of the testes. The seasonal variations in colour and 
consistency of semen, proportion of dead spermatozoa and scrotal volume were of smaller magnitude and the total number of spermatozoa in the ejaculate did not vary between seasons. There was a large difference in semen mass motility between the transitional dry-rainy and the other 3 seasons, the former showing a much reduced value. The forward motility score showed a similar trend. The concentration of spermatozoa in the semen was significantly lower in the rainy and the subsequent transitional rainy-dry seasons. There was some indication of ram $\times$ period interaction in ejaculate volume, various motility scores and the length of the testes.

During the year, the rams showed marked changes in body weight, and this was used as a covariate in the analysis. Body weight was closely related to all the testis measurements and the forward motility score for spermatozoa, but no association was found with other characteristics of semen.

\section{Discussion}

When sheep breeds are imported from temperate regions to tropical areas, they suffer from seminal degeneration during very hot parts of the year, resulting in 'summer sterility' (Sahni \& Roy, 1967). The magnitude of such effects may vary with the breed (Mittal \& Ghosh, 1979). The Brazilian Somali breed is a more or less adapted type, the foundation stock coming from near-tropical areas in East Africa. Therefore, the pattern of seasonal variation in semen quality is expected to be different from that observed in temperate breeds exposed to severe hot climates. The results showed that the seasonal variation, although significant, was much less than has been observed by other workers (Dutt \& Bush, 1955; Sahni \& Roy, 1967; Tiwari \& Sahni, 1975) and semen was usable throughout the year. Mittal \& Ghosh (1979) have stated that, in the very hot seasons of arid regions of India, imported Corriedale rams donated semen of usable quality and this was ascribed to the very low humidity and large diurnal variation in environmental temperature which was always low during the night. The role of low night temperatures in arid regions has also been discussed by Hafez, Badreldin \& Darwish (1955) and Amir \& Volcani (1965) and seasonal variation had little influence on semen quality of rams (Amir \& Volcani, 1965; Galal, El-Gamal, AboulNaga \& El-Fouly, 1978; Chiboka, 1980).

The ejaculate volume and motility scores had higher values during the rainy and the subsequent transitional season. Although several studies, including those of Kaushish \& Sahni (1976) and Riveros \& Corvalán (1979), show no association between nutrition and semen characteristics, in the present study this effect perhaps has more to do with the availability of green fodder during the rainy and in subsequent transitional period, resulting in a general improvement in the condition of the rams. The level of feeding has been shown to influence sperm production of rams (Salamon, 1964; Braden, Turnbull, Mattner \& Moule, 1974).

Rams vary greatly in testicular size and the rate of sperm production per unit of testis weight is constant (Lino, 1972; Gherardi, Lindsay \& Oldham, 1980). Gherardi et al. (1980) showed that improved feeding resulted in increased size of testes and such rams were capable of mating with a larger number of ewes. Braden et al. (1974) also showed that the testis size was influenced by the protein and energy levels in the diet. In the present study, there was a marked seasonal difference in all testis measurements, except consistency score. Similar seasonal variation was also reported by Islam \& Land (1977). In this study, all testis measurements were related to body size. Land \& Sales (1977) and Abdelhakeam, El-Alamy, Tony \& Yassen (1978) also reported similar associations. The ram $\times$ season interaction was significant for testis length, but not for other testis measurements. Thus, testis measurements showed almost uniform variation in the seasons in all the rams. A significant breed $\times$ season interaction in testis size was reported by Islam \& Land (1977).

We thank José Martins, José Medeiros, Ana Maria Vasconcelos and Luiz Rodrigues for technical help. 


\section{References}

Abdelhakeam, A., El-Alamy, M.A., Tony, S.M. \& Yassen, A.M. (1978) Testicular growth in Ossimi rams and related epididymal sperm reserves measured by depletion. Alexandria J. Agric. Res. 26, 569-574.

Amir, D. \& Volcani, R. (1965) Seasonal fluctuations in the sexual activity of Awassi, German Mutton Merino, Corriedale, Border Leicester and Dorset Horn rams. II. Seasonal changes in semen characteristics. $J$. agric. Sci., Camb. 64, 121-125.

Barr, A.J., Goodnight, J.H., Sall, J.P. \& Helwig, J.T. (1976) A User's Guide to SAS 76. SAS Institute, Raleigh, North Carolina.

Braden, A.W.H., Turnbull, K.E., Mattner, P.E. \& Moule, G.R. (1974) Effect of protein and energy content of diet on the rate of sperm production in rams. Aust. $J$. biol. Sci. 27, 67-73.

Chiboka, O. (1980) Semen characteristics of West African Dwarf rams. Anim. Reprod. Sci. 3, 247-252.

Dutt, R.H. \& Bush, L.F. (1955) The effect of low environmental temperature on initiation of the breeding season and fertility in sheep. J. Anim. Sci. 14, 885-896.

Figueiredo, E.A.P., Simplício, A.A. \& Pant, K.P. (1982) An evaluation of sheep breeds for early growth in the tropical North-East Brazil. Trop. Anim. Hlth Prod. 14 (in press.)

Galal, E.S.E., El-Gamal, A.A., Aboul-Naga, A. \& ElFouly, M.A. (1978) Male reproductive characteristics of Merino and Ossimi sheep and their crosses. Anim. Prod. 27, 261-267.

Gherardi, P.B., Lindsay, D.R. \& Oldham, C.M. (1980) Testicular size in rams and flock fertility. Anim. Prod. Australia 13, 48-50.

Hafez, E.S.E., Badreldin, A.L. \& Darwish, Y.H. (1955) Seasonal variations in the semen characteristics of sheep in sub-tropics. J. agric. Sci., Camb. 45, 283-292.

Hahn, J., Foote, R.H. \& Seidel, G.E. (1969) Testicular growth and related sperm output in dairy bulls. $J$. Anim. Sci. 29, 41-47.

Islam, A.B.M.M. \& Land, R.B. (1977) Seasonal variation in testis diameter and sperm output of rams of different prolificacy. Anim. Prod. 25, 311-317.
Kaushish, S.K. \& Sahni, K.L. (1976) Effect of feeding animal protein (egg-milk) and trace elements and provision of cooler climate on libido, semen quality and certain physiological reactions of Russian Merino rams during summer season. Indian J. Anim. Sci. 46, 135-139.

Land, R.B. \& Sales, D.T. (1977) Mating behaviour and testis growth of Finnish Landrace, Tasmanian Merino and crossbred rams. Anim. Prod. 24, 83-90.

Lino, B.F. (1972) The output of spermatozoa in rams. II. Relationship to scrotal circumference, testes weight and number of spermatozoa in different parts of the urogenital tract. Aust. J. biol. Sci. 25, 359-366.

Mason, I.L. (1980) Sheep and goat production in the drought polygon of Northeast Brazil. World Anim. Rev. No. 34, 23-28.

Mies Filho, A. (1975) Reprodução dos Animais e Inseminação Artificial, 3rd edn, Vol. 2, p. 393. Livraria Sulina, Porto Alegre.

Mittal, J.P. \& Ghosh, P.K. (1979) Comparative semen characteristics of Corriedale, Marwari and Jaisalmeri rams maintained under hot conditions. J. agric. Sci., Camb. 92, 1-4.

Riveros, V.E. \& Corvalán, L.A. (1979) Influência de caroteno y vitamina A sobre la fertilidade de machos ovinos en ecosistema pastorales semiáridos. Avances Prod anim. 4, 55-63.

Sahni, K.L. \& Roy, A. (1967) A note on summer sterility in Romney Marsh rams under tropical conditions. Indian J. vet. Sci. 37, 335-338.

Salamon, S. (1964) The effect of nutritional regimen on the potential semen production of rams. Aust. J. agric. Res. 15, 645-656.

Shelton, M. \& Figueiredo, E.A.P. (1981) Types of sheep and goats in Northeast Brazil. Int. Sheep and Goat Res. 1, 258-268.

Tiwari, S.B. \& Sahni, K.L. (1975) Semen quality of Rambouillet rams and its crosses (with the native) during hotter part of the year. Indian vet. J. 52, 614 619.

Received 19 May 1982 